\title{
Human Autoantibodies to Poly(Adenosine Diphosphate-Ribose) Polymerase Recognize Cross-reactive Epitopes Associated with the Catalytic Site of the Enzyme
}

\author{
Hisashi Yamanaka, Erik H. Willis, and Dennis A. Carson \\ Department of Basic and Clinical Research, Research Institute of Scripps Clinic, La Jolla, California 92037
}

\begin{abstract}
The factors responsible for the production of autoantibodies against self-components are not well understood. We have identified monospecific human autoantibodies to poly(ADP-ribose) polymerase (ADPRP) in the sera of rheumatic patients. Since this nuclear enzyme has been extensively characterized, and its entire structure is known, we could investigate in detail the epitope specificity of the human autoantibodies, and their effects on the biological functions of the enzyme. All sera with autoantibodies to ADPRP recognized the NAD-binding domain of the enzyme, as demonstrated by either immunoblotting or immunoprecipitation of partially proteolyzed ADPRP. The autoantibodies also inhibited the catalytic activity of the purified enzyme, as measured by the transfer of ADP-ribose from [ ${ }^{32}$ P]NAD to either histones or to ADPRP itself. Because comparative structural analyses have shown that the active sites of enzymes are often conserved during evolution, we tested the ability of the autoantibodies to react with ADPRP from lower eukaryotes. The human autoantibodies reacted with ADPRP in cellular extracts from mammalian, avian, amphibian, arthropod, and protozoan cells, and also inhibited the catalytic activity of the various enzymes. Collectively, these experiments indicate that the human autoantibodies to ADPRP recognize a distinct group of evolutionarily conserved antigenic determinants that are closely related to the catalytic site of the enzyme. The results are consistent with the hypothesis that the epitope selectivity of human autoantibodies to ADPRP is influenced by cross-reactive antigens in the external environment.
\end{abstract}

\section{Introduction}

Nuclear proteins are common targets of autoimmune responses in patients with systemic rheumatic diseases $(1,2)$. It is still not clear how abnormal immune regulation leads to the repeated production of autoantibodies against such a highly selected group of self-components. To approach this problem,

Portions of this work were presented in abstract form in November 1987 at the Western Regional Meeting of the American Rheumatism Association, in San Diego, CA.

Dr. Yamanaka's present address is Institute of Rheumatology, Tokyo Women's Medical College, NS Bldg., 2-4-1 Nishi-Shinjuku, Shinjuku-ku Tokyo 163, Japan.

Address reprint requests to Dr. Carson.

Received for publication 1 February 1988 and in revised form 8 July 1988.

J. Clin. Invest.

(c) The American Society for Clinical Investigation, Inc.

0021-9738/89/01/0180/07 \$2.00

Volume 83, January 1989, 180-186 it is important to localize the exact autoantigenic epitopes on nuclear proteins. However, the performance of such investigations requires knowledge of the structure and biological function of the antigen under analysis.

Recently, we identified high titer and monospecific autoantibodies against poly(ADP-ribose) polymerase (ADPRP) ${ }^{1}$ in several rheumatic patients (3). ADPRP [E.C. 2.4.2.30] is a eukaryotic nuclear enzyme that has been characterized extensively $(4,5)$. Recently, cDNA clones of the human enzyme have been isolated, and its sequence has been completely determined (6-8). ADPRP consists of a single 116-kD polypeptide that catalyzes the DNA-dependent transfer of ADP-ribose units from NAD to nuclear proteins, to form elongated and branched poly(ADP-ribose) chains (4). This posttranslational modification of nuclear proteins occurs particularly at regions of DNA strand break formation $(4,9)$, and may be important in the modulation of chromatin structure that accompanies DNA repair (10) and cell differentiation (11) in eukaryotes.

In this report, we have investigated the specificities of the human autoantibodies against ADPRP, and their effects on the biological function of the enzyme. Our results demonstrate that the autoantibodies all recognize an epitope that is associated with the catalytic site of ADPRP, and that is expressed by the enzyme in both higher and lower eukaryotes. The restricted specificity and cross-reactivity of the autoantibodies to ADPRP are consistent with the hypothesis that antigens in the external environment influence the epitope specificity of human autoantibodies to nuclear proteins.

\section{Methods}

Autoantibodies. The sera containing autoantibodies against ADPRP have been described previously (3). The IgG fractions were purified by ammonium sulfate precipitation, followed by DEAE column chromatography (12). In some experiments, antibodies were purified by affinity chromatography, using an ADPRP-conjugated Sepharose column, as described earlier (3).

Cell extracts. The following cells were cultured in Dulbecco's modified Eagle's medium supplemented with $4 \mathrm{mM}$ L-glutamine, nonessential amino acids, and $10 \%$ fetal bovine serum (M. A. Bioproducts, Walkersville, $\mathrm{MD}$ ) in $5 \% \mathrm{CO}_{2}$ in air at the indicated temperatures: HeLa S3 (Human ATCC CCL2.2, $37^{\circ} \mathrm{C}$ ); MDBK (bovine ATCC CLL 22, $37^{\circ} \mathrm{C}$ ); $3 \mathrm{~T} 3$ (mouse, ATCC CCL $92,37^{\circ} \mathrm{C}$ ); duck embryo cells (ATCC CCL141, $37^{\circ} \mathrm{C}$ ); rainbow trout RTG-2 cells (ATCC CCL 55, $22^{\circ} \mathrm{C}$ ); and Aedes albopictus clone C6/36 (mosquito, ATCC CRL1660, $22^{\circ} \mathrm{C}$ ). Human T lymphoblastoid cells (CCRF-CEM, ATCC 119) were cultured in RPMI 1640 medium supplemented with $2 \mathrm{mM}$ L-glutamine and $10 \%$ fetal bovine serum. Crithidia luciliae (ATCC 30258) were maintained at $25^{\circ} \mathrm{C}$ in ATCC medium $355(6.0 \mathrm{~g}$ trypticase, $1.0 \mathrm{~g}$ yeast extract, $0.1 \mathrm{~g}$ liver concentrate, $120 \mathrm{~g}$ sucrose, $25 \mathrm{mg}$ hemin, and

1. Abbreviation used in this paper: ADPRP, poly(ADP-ribose) polymerase. 
$25 \mathrm{ml}$ triethanolamine per liter, $\mathrm{pH}$ 7.8). Xenopus eggs (dejellied by dimethylsulfoxide) were kindly provided by Drs. M. Ryuji and W. Yasui, and an extract of Trypanosoma rangeli d'Allessandro (13) by Dr. G. Harth (all from the Research Institute of Scripps Clinic).

All cells were washed with ice-cold isotonic buffered saline, $\mathrm{pH} 7.4$ (PBS), after which the pellets were either processed immediately or kept frozen at $-80^{\circ} \mathrm{C}$ until the preparation of extracts. The cells were suspended in ice-cold buffer A (10 mM Tris- $\mathrm{HCl}, \mathrm{pH} \mathrm{7.4,150 \textrm {mM }}$ $\mathrm{NaCl}, 10 \mathrm{mM} \mathrm{MgCl}$, and $0.5 \%$ Nonidet $\mathrm{P}-40$ ) supplemented with 1 mM phenylmethylsulfonyl fluoride (PMSF). After brief sonication $(\sim 5 \mathrm{~s})$, precipitated material was removed by centrifugation $(10,000$ g, $5 \mathrm{~min}, 4^{\circ} \mathrm{C}$ ).

Immunoblotting. Crude cell extracts or purified ADPRP were fractionated on a $12.5 \%$ polyacrylamide gel containing $0.1 \%$ sodium dodecyl sulfate (SDS), and transferred to nitrocellulose. ADPRP was detected by immunoblotting either with patient's serum containing autoantibodies to ADPRP (1:100 in 3\% powdered milk in PBS) or with affinity purified anti-ADPRP IgG $(10 \mu \mathrm{g} / \mathrm{ml}, 3 \%$ powdered milk in PBS). Bound antibody was detected with ${ }^{125}$ I-labeled protein A (ICN Radiochemicals, Irvine, CA), exactly as described previously (3).

Purification of ADPRP. ADPRP was purified from fresh-frozen calf thymus (Pel-Freeze Biologicals, Rogers, AK), as described previously (14). As tested by either protein staining or immunoblotting, the purified enzyme yielded a single band after electrophoretic separation in polyacrylamide gels containing $0.1 \%$ SDS (14).

Epitope mapping of ADPRP by autoantibodies. Purified calf thymus ADPRP $(5 \mu \mathrm{g})$ was partially proteolyzed with either $\alpha$-chymotrypsin $\left(1.5 \mu \mathrm{g} / \mathrm{ml}, 25^{\circ} \mathrm{C}, 5 \mathrm{~min}\right)$ or papain-agarose $\left(0.15 \mathrm{mg} / \mathrm{ml}, 0^{\circ} \mathrm{C}\right.$, $5 \mathrm{~min}$ ), according to methods described previously (15). The reactions were terminated by addition of PMSF, or by centrifugation. The resultant polypeptide fragments were solubilized in Laemmli's sample buffer containing $2 \%$ SDS (16), and then were fractionated by SDSpolyacrylamide gel electrophoresis, transferred to nitrocellulose filters, and immunoblotted.

Automodification and histone modification by ADPRP. In the presence of nicked DNA, ADPRP catalyzes the transfer of ADP-ribose from NAD to the enzyme itself (4). In a typical automodification reaction, purified calf thymus ADPRP $(0.2 \mu \mathrm{g})$ was incubated for 5 min at $37^{\circ} \mathrm{C}$ with sonicated calf thymus DNA $(0.1 \mathrm{mg} / \mathrm{ml})$ and $\left[{ }^{32} \mathrm{P}\right]-$ NAD (New England Nuclear, Boston, MA; $0.1 \mu \mathrm{Ci} / \mathrm{sample}, 0.06 \mu \mathrm{M}$ NAD), in automodification buffer (100 mM Tris-HCl, pH 8.0, $50 \mathrm{mM}$ $\mathrm{NaCl}, 2 \mathrm{mM} \mathrm{MgCl}$, $1 \mathrm{mM}$ DTT, and $1.5 \mathrm{mM}$ EDTA). When histones were the target of poly(ADP-ribosyl)ation, calf thymus histone (U. S. Biochemicals, Cleveland, $\mathrm{OH} ; 0.1 \mathrm{mg} / \mathrm{ml}$ ) was included in the reaction mixture, and the final NAD concentration was $0.6 \mu \mathrm{M}$. Immediately after the reactions, proteins were solubilized in Laemmli's sample buffer by boiling for $2 \mathrm{~min}$. Then, they were separated by electrophoresis on a $0.1 \%$ SDS- $12.5 \%$ polyacrylamide gel, and visualized by autoradiography. In some experiments, either purified ADPRP or crude cell extracts were preincubated for $1 \mathrm{~h}$ at $4^{\circ} \mathrm{C}$ with either $(a) 5 \mathrm{mM}$ 3-aminobenzamide, a potent inhibitor of ADPRP (17), (b) normal human IgG $(10-50 \mu \mathrm{g} / \mathrm{ml})$ or $(c)$ IgG with autoantibodies to ADPRP (10-50 $\mu \mathrm{g} / \mathrm{ml}$ ), before initiation of the automodification reactions.

DNA-binding assay. DNA from human CEM T lymphoblastoid cells was first digested completely with Eco RI $\left(10 \mathrm{U} / \mu \mathrm{g}\right.$ DNA, $37^{\circ} \mathrm{C}$ for $16 \mathrm{~h}$ ). After fractionation by polyacrylamide gel electrophoresis, DNA fragments of $\sim 300$ bp were eluted from the gel and purified by phenol/chloroform extraction followed by ethanol precipitation. The 300-bp DNA was end-labeled with [ $\left.\alpha{ }^{32} \mathrm{P}\right] \mathrm{dATP}$ (ICN Radiochemicals), using Klenow fragment of DNA polymerase I, to a specific activity of $10^{8} \mathrm{cpm} / \mu \mathrm{g}$ DNA (18). A filter-binding assay was employed for the detection of DNA-protein complexes (19). Purified ADPRP (20 ng per sample) was preincubated with IgG for $1 \mathrm{~h}$ at $4^{\circ} \mathrm{C}$ in a DNA-binding buffer ( $50 \mathrm{mM}$ Tris- $\mathrm{HCl}$, pH 8.0, $50 \mathrm{mM} \mathrm{NaCl}, 2 \mathrm{mM}$ DTT, and 2 $\mathrm{mM} \mathrm{MgCl}$ ). Thereafter, ${ }^{32} \mathrm{P}$-labeled DNA (1 ng) was added. The reaction mixtures were incubated for $30 \mathrm{~min}$ at room temperature, and then were applied to nitrocellulose filters (BA85, Schleicher \& Schuell, Inc., Keene, $\mathrm{NH}$ ) that had been previously treated with $0.2 \mathrm{M} \mathrm{KOH}$, as reported (19). The filters were washed with DNA-binding buffer, and the radioactivity remaining on the filters was determined by liquid scintillation counting.

Immunoprecipitation of automodified ADPRP. Various cell extracts were incubated for 5 min with [ $\left.{ }^{32} \mathrm{P}\right] \mathrm{NAD}$, calf thymus DNA, and DNase I (DPRF, Cooper Biomedical, Malvern, PA) to activate ADPRP maximally. Then, the reaction mixtures were incubated at $4^{\circ} \mathrm{C}$ with purified IgG autoantibodies, or with normal IgG, each of which had been previously conjugated to protein A-Sepharose beads (Pharmacia Fine Chemicals, Piscataway, NJ). The incubation buffer contained $50 \mathrm{mM}$ Tris- $\mathrm{HCl}, \mathrm{pH} 7.4,150 \mathrm{mM} \mathrm{NaCl}, 0.5 \%$ Nonidet P-40, $0.5 \%$ sodium deoxycholate, $0.1 \%$ SDS, and $1 \mathrm{mM}$ PMSF. One hour later, the beads were washed five times with the same buffer, and the bound proteins were solubilized in Laemmli's sample buffer by boiling for $3 \mathrm{~min}$. The solubilized proteins were fractionated by SDSpolyacrylamide gel electrophoresis, and radiolabelled bands were visualized by autoradiography (3).

\section{Results}

Localization of autoantigenic epitopes on ADPRP. The 116kD ADPRP polypeptide has separate NAD-binding, automodification, and DNA-binding domains that can be separated after limited proteolysis of the enzyme with $\alpha$-chymotrypsin or papain $(15,20)$. The size of these domains has been clarified by the recent sequencing of cDNA clones for ADPRP, and by the isolation of the homogenous human enzyme in quantity (6-8, 20). As illustrated in Fig. 1, partial digestion of ADPRP with $\alpha$-chymotrypsin can yield fragments of $40,54,62$, and $76 \mathrm{kD}$. The 54-kD fragment contains the entire NAD-binding domain, while the $62-\mathrm{kD}$ fragment contains the automodification site and the DNA-binding domain. The 76-kD chymotryptic fragment includes a portion of the NAD-binding domain, the automodification site, and the entire DNA-binding domain.

As shown in Fig. 1, all of seven sera with antibodies against ADPRP reacted on immunoblots not only with the intact 116-kD ADPRP polypeptide, but also with the 54-kD NADbinding chymotryptic fragment (left panel). These sera similarly detected the $72-\mathrm{kD}$ product of limited papain digestion (right panel), that also contains the NAD-binding domain. In contrast, only three out of seven sera (lanes 1,6 , and 7) immunoblotted the $62-\mathrm{kD}$ chymotryptic fragment that contains the DNA-binding domain. Serum ED (lane 1 in Fig. 1), has been shown previously to immunoprecipitate the $62-\mathrm{kD}$ chymotryptic fragment and the $72-\mathrm{kD}$ papain fragment of ADPRP (3), but reacted weakly with these bands on immunoblots. In no other case was a discrepancy observed between the results obtained with immunoblotting and immunoprecipitation. Together, the data indicate that all the human autoantibodies react with the NAD-binding domain of ADPRP, whereas three out of seven autoantibodies recognize both the DNA-binding and the NAD-binding domains of the enzyme.

Inhibition of automodification and histone modification by autoantibodies. The effects of the two types of autoantibodies on the transfer of $\left[{ }^{32} \mathrm{P}\right] A D P$-ribose from NAD either to the enzyme itself, or to histones, were examined. After automodification of ADPRP in the presence of $\left[{ }^{32} \mathrm{P}\right] \mathrm{NAD}$ and SDSpolyacrylamide gel electrophoresis, a characteristic radioactive smear was observed at $116 \mathrm{kD}$ and above, representing varying degrees of poly(ADP-ribosyl)ation (Fig. $2 A$ ). When calf thymus histones were included in the reaction mixture, a $32-\mathrm{kD}$ radiolabeled band was also visualized (Fig. 2 B), corre- 


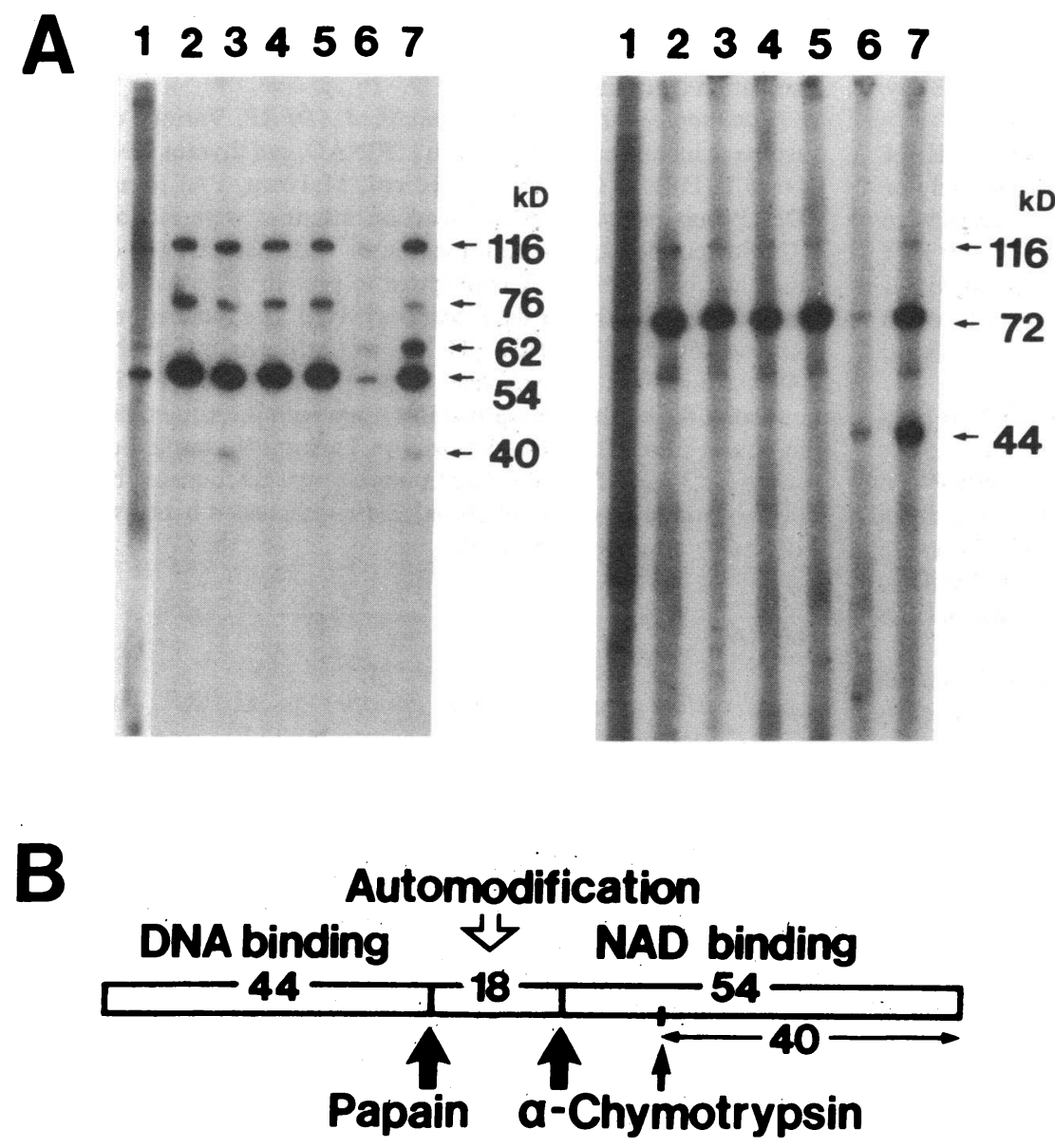

Figure 1. Reactivity of autoantibodies with proteolytic fragments of ADPRP. $(A)$ Purified ADPRP was partially digested with $\alpha$-chymotrypsin (left panel) or papain (right panel) and the enzymatically generated fragments were separated by SDS-polyacrylamide gel electrophoresis. After transfer to nitrocellulose, polypeptides were immunoblotted with patients' sera (lanes 1-7, 1:100 dilution) containing autoantibodies to ADPRP. Note that all sera bound the 54-kD chymotryptic fragment, but only three reacted with the $62-\mathrm{kD}$ chymotryptic fragment. The 54-kD fragment contains the NAD-binding domain, while the $62-\mathrm{kD}$ fragment includes the automodification site and the DNA-binding domain $(15,20)$. The thick arrows in $B$ show the major sites of $\alpha$-chymotrypsin and papain cleavage; the thin arrow points to a secondary site of $\alpha$-chymotrypsin digestion. In previous reports, the sizes of the DNA binding and automodification domains were overestimated $(3,15)$.

sponding to histone $\mathrm{H} 1$. These poly(ADP-ribosyl)ation reactions were totally inhibited by the ADPRP inhibitor, 3-aminobenzamide, but were not affected by normal IgG. The antiADPRP autoantibodies from patient $E D$, that react with both the NAD-binding and DNA-binding domains, blocked the poly(ADP-ribosyl)ation reactions. However, the autoantibodies from patient $C M$ (lane 2 in Fig. 1), that recognize exclusively the 54-kD NAD-binding domain of ADPRP, also inhibited enzyme activity. These results indicate that autoantibody interaction with the NAD-binding domain is sufficient to block ADPRP catalytic activity.
Inhibition of ADPRP interaction with $D N A$. The catalytic activity of ADPRP is strongly stimulated by DNA, especially by DNA with breaks or nicks (9). To prove that the autoantibodies from patient $\mathrm{CM}$ did not impair the interaction of ADPRP with DNA, DNA-protein binding assays were performed. These experiments were possible because the tested sera with anti-ADPRP autoantibodies lacked detectable antiDNA antibody activity (3). As shown in Table I, the formation of a protein-DNA complex was perturbed by preincubation of ADPRP with autoantibodies with specificity for both the DNA-binding and NAD-binding domains (ED IgG, Table I).

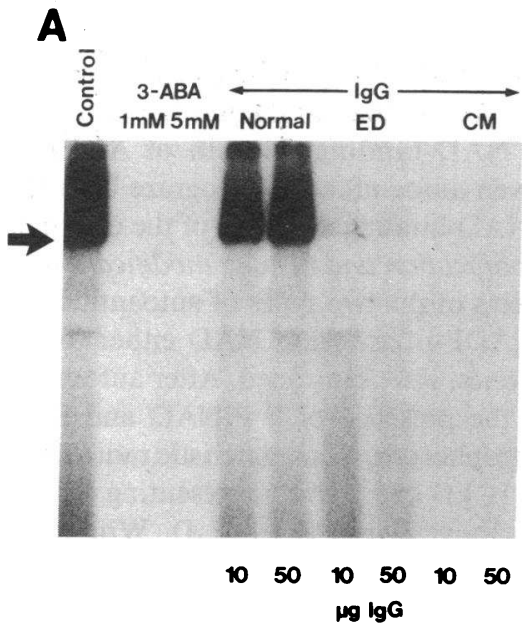

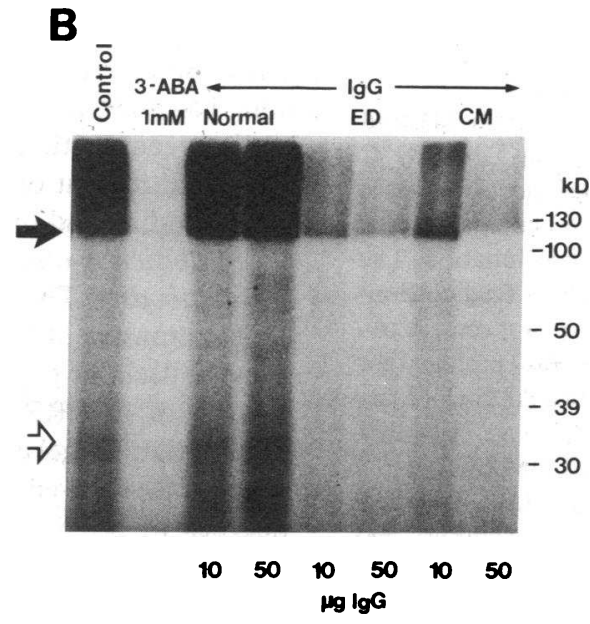

Figure 2. Inhibition of $(A)$ automodification and $(B)$ histone modification of purified ADPRP by human autoantibodies. $(A)$ Calf thymus ADPRP was automodified with [2P]NAD. The enzyme was preincubated with buffer alone (control), with 3-aminobenzamide (3-ABA), with normal IgG, with IgG of patient $E D$, or with IgG of patient $C M$. (B) Histone modification was similarly tested, using the same conditions described in $A$, except that calf thymus histones were included in the reaction mixture. The molecular mass of ADPRP (116-kD, solid arrow) and histone $\mathrm{H} 1$ ( $32 \mathrm{kD}$, open arrow) is indicated on the left margin. 
Table 1. Inhibition of DNA Binding to ADPRP by Human Autoantibodies

\begin{tabular}{cccc}
\hline & \multicolumn{3}{c}{ CPM DNA bound } \\
\cline { 2 - 4 } Amount of IgG & Normal IgG & $E D$ IgG & \multicolumn{1}{c}{$C M$ IgG } \\
\hline$\mu g$ & & $c p m$ & \\
10 & $13,127 \pm 176$ & $10,336 \pm 2,225$ & $12,109 \pm 616$ \\
50 & $12,687 \pm 390$ & $5,809 \pm 553$ & $12,322 \pm 1,332$
\end{tabular}

Purified calf thymus ADPRP ( $20 \mathrm{ng}$ ) was mixed with IgG from normal subjects, or from two patients with autoantibodies to ADPRP. Then, the enzyme IgG mixtures were incubated with human DNA labeled with $\left[\alpha-{ }^{32} \mathrm{P}\right] \mathrm{dATP}(\sim 16,000 \mathrm{cpm}, 1 \mathrm{ng}, 300 \mathrm{bp}$ in length). 30 min later, the mixtures were passed through $\mathrm{KOH}$-treated nitrocellulose filters, washed, and counted. The results represent the mean $\pm S D$ of three separate experiments.

However, when compared to normal IgG, the binding was not altered by IgG autoantibodies directed exclusively against the NAD-binding domain ( $C M$ IgG, Table I). Thus, the ability of $C M$ IgG to inhibit the catalytic activity of ADPRP could not be attributed to obstruction of DNA-binding but rather was related to interference with substrate (NAD) binding.

Species cross-reactivity of the human autoantibodies to $A D P R P$. The ability of the human autoantibodies against ADPRP to bind the enzyme from other species was examined by immunofluorescence, immunoblotting, and immunoprecipitation. The autoantibodies yielded the same characteristic immunofluorescent pattern with human, duck, fish, and mosquito cells (results not shown), showing nuclear staining with a characteristic nucleolar accentuation (3). As tested by immunoblotting, affinity-purified human autoantibodies to ADPRP also recognized $116-\mathrm{kD}$ protein bands in mammalian, avian, amphibian, and protozoan extracts (e.g., Fig. 3), as well as a band of $\approx 64 \mathrm{kD}$ in several cases. In extracts prepared from the mosquito, Aedes albopictus, only the smaller band was detected. In human cells, previous experiments have suggested that the smaller bands are degradation fragments of the intact ADPRP protein, because antibodies that were eluted from the bands reacted with the 116-kD enzyme molecule (3). However, the possibility that they represent other antigenically cross-reactive proteins cannot be excluded.

To ascertain that the ADPRP polypeptides from human and lower eukaryotes share an autoantigenic epitope, immunoprecipitation experiments were performed, taking advantage of the unique ability of the enzyme to undergo automodification. Crude extracts from HeLa cells, Xenopus eggs and Crithidia luciliae were incubated with [ ${ }^{32}$ P]NAD, DNA, and DNase I, to label specifically ADPRP, and then were reacted with the human autoantibodies, or with normal IgG. The human autoantibodies, but not control IgG, immunoprecipitated the $\left.{ }^{32} \mathrm{P}\right] N A D-l a b e l e d$ poly(ADP-ribosyl)ated protein in all three extracts (Fig. $4 \mathrm{~A}$ ). In HeLa and Xenopus extracts, radioactive smears of $116 \mathrm{kD}$ and higher were visualized; in Crithidia $80-100-\mathrm{kD}$ bands were observed. The heterogenous molecular mass of the radiolabeled polypeptides probably reflects the variable length of the ADP-ribose chains, and perhaps the partial proteolysis of the enzyme. Indeed, ADPRP activity in Crithidia was only detectable if the cells were ex-

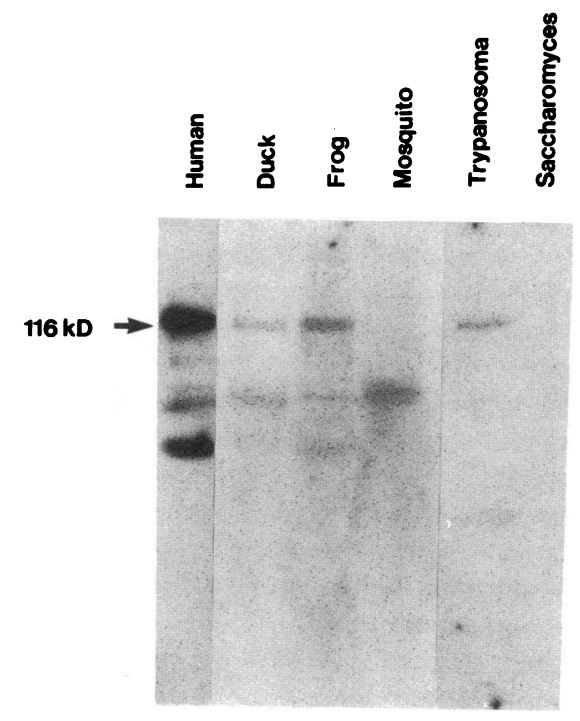

Figure 3. Immunoblotting of eukaryotic cell extracts. Extracts of human (HeLa cells, $64 \mu \mathrm{g}$ protein), avian (duck embryo cells, $100 \mu \mathrm{g}$ protein), amphibian (Xenopus eggs, $100 \mu$ g protein), arthropod (Aedes albopictus, $\mathrm{C} 6 / 36$ cells, $100 \mu \mathrm{g}$ protein), protozoa (Trypanosoma rangeli, $100 \mu \mathrm{g}$ protein) and yeast (Saccharomyces, $100 \mu \mathrm{g}$ protein) were immunoblotted with affinity-purified IgG to ADPRP, as described in Methods.

tracted into buffer containing protease inhibitors, and were processed immediately.

Finally, to confirm that the cross-reactive human autoantibodies to ADPRP recognized determinants related to the catalytic site of the enzyme, the effects of IgG on enzymatic activity were tested. In both HeLa cells and Xenopus eggs, enzyme automodification was inhibited by 3-aminobenzamide and by human autoantibodies to ADPRP, but not by normal IgG. In Crithidia extracts, the poly(ADP-ribosyl)ated bands that were observed at $\sim 75$ and $50 \mathrm{kD}$, were also specifically inhibited by 3-aminobenzamide and by human autoantibodies (Fig. 4 B). Similar experiments demonstrated the ability of the autoantibodies to inhibit ADPRP activity in mammalian, avian, arthropod, and protozoan cells (results not shown).

\section{Discussion}

Among the thousands of different proteins that can be produced by human cells, less than 100 have thus far been shown to be recognized by autoantibodies in patients with rheumatic diseases. Structural and molecular analyses of several protein autoantigens have revealed certain recurrent properties, although no absolute associations (1). Many autoantigens are relatively abundant proteins, that often are organized into particulate, multifunctional complexes involved in DNA replication, transcription, or translation $(21,22)$. The autoantigenic proteins frequently have either local areas of charge, or repeating sequences, that facilitate their interaction with DNA and RNA $(23,24)$. Because of their essential roles in cellular metabolism, the basic structures of nuclear proteins tend to be conserved among species $(2,25)$.

Recent experiments have revealed that ADPRP is also an abundant DNA-binding protein. As an example, human lymphocytes have been estimated to contain $1 \times 10^{6}$ ADPRP 


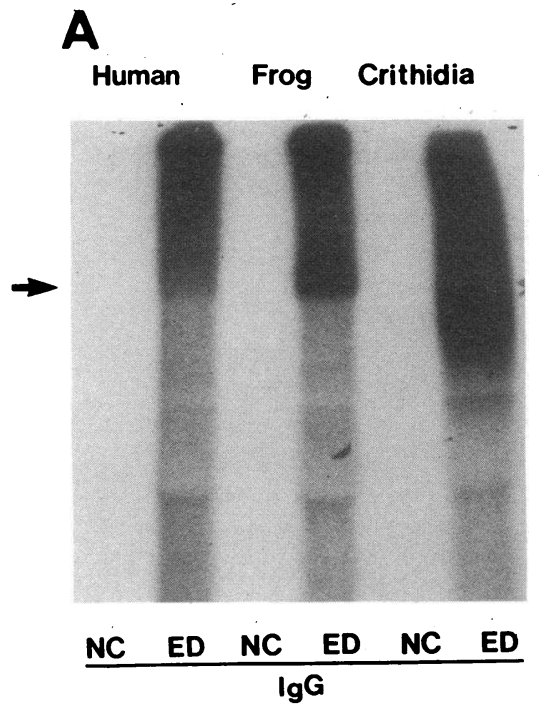

Figure 4. (A) Immunoprecipitation of automodified ADPRP and $(B)$ inhibition of automodification of ADPRP in lower eukaryotes by human autoantibodies. ( $A$ ) Extracts of human (HeLa), amphibian (Xenopus eggs) and protozoan cells (Crithidia luciliae) were poly(ADP-ribosyl)ated with [ $\left.{ }^{32} \mathrm{P}\right] \mathrm{NAD}$, and immunoprecipitated with IgG of normal controls $(N C)$ or with IgG of a patient $(E D)$ with autoantibodies to ADPRP. (B) Extracts of human (HeLa cells), am-

molecules per cell (14). The enzyme is ubiquitous in vertebrate species, and has been detected even in parasitic protozoa, including Plasmodia (26), Trypanosoma (27), and Crithidia (28). Although minor differences have been observed in the peptide maps of ADPRP purified from different sources (20), the molecular mass of the single ADPRP polypeptide chain is conserved among mammals, arthropods, and mollusks (28). Thus, ADPRP resembles other autoantigenic nuclear proteins in several respects.

However, ADPRP has the unique ability to catalyze the sequential transfer of ADP-ribose residues from NAD to the enzyme molecule itself (4). This automodification reaction modulates the interaction of ADPRP with DNA, and may also play a role in the regulation of NAD turnover (29). 3-Aminobenzamide is an established inhibitor of ADPRP (17). Using crude extracts incubated with [ $\left.{ }^{32} \mathrm{P}\right] \mathrm{NAD}$ in the presence or absence of 3-aminobenzamide, we could both test for ADPRP enzymatic activity in different cells, and study the ability of human autoantibodies to immunoprecipitate the radiolabelled ADPRP polypeptide. The results showed that the autoantibodies recognized automodified ADPRP in vertebrates, arthropods, and protozoa. These conclusions were confirmed by immunoblotting and immunofluorescent experiments utilizing autoantibodies purified by affinity chromatography.

When added prior to NAD, the human autoantibodies against ADPRP inhibited the poly(ADP-ribosyl)ation of histone $\mathrm{Hl}$, as well as the automodification reaction. ADPRP requires DNA for catalytic activity, and is strongly activated by double-stranded DNA with nicks or breaks. ADPRP contains distinct DNA-binding and NAD-binding domains that can be separated by partial proteolysis of the enzyme $(15,20)$. In principle, the autoantibodies could interfere with ADPRP catalytic activity by binding to one or both domains. However, immunoprecipitation and immunoblotting experiments showed that all the autoantibodies reacted with the NADbinding domain, while only three of seven recognized both domains. Furthermore, autoantibodies that recognized exclusively the NAD-binding domain could block ADPRP catalytic activity.

Recently, cDNA clones for human ADPRP have been isolated, and the entire primary structure of the enzyme has been determined $(6-8,30)$. In addition, bacterial fusion proteins that express the major autoantigenic epitope in the NAD-binding domain have been generated (30). This autoantigenic fragment of ADPRP has a predicted secondary structure that is reminiscent of other NAD-utilizing dehydrogenases. A portion of the NAD-binding region is both hydrophilic and flexible, and therefore should be readily accessible to autoantibodies (C. Penning, H. Yamanaka, D. A. Carson, et al., unpublished observations). Taken together with the results of the present experiments, these considerations suggest that the principal autoantigenic epitope on ADPRP is closely related to the NAD-binding catalytic site.

The structural characteristics of the nucleotide binding domains of enzymes generally have been conserved during molecular evolution, since they are under selective pressure to maintain a unique function $(31,32)$. Hence, the recognition of the NAD-binding site of ADPRP by the human autoantibodies is entirely consistent with their ability to immunoprecipitate the enzyme from evolutionarily divergent species, and to inhibit the poly(ADP-ribosyl)ation reaction. The results emphasize the close relationship between the conserved catalytic site of this nuclear enzyme and its major autoantigenic epitope.

In summary, these experiments have shown $(a)$ that the NAD-binding region of ADPRP is the only part of the molecule that is recognized by every sera containing autoantibodies against the enzyme, $(b)$ that the autoantibodies recognize 
ADPRP in diverse eukaryotes, and (c) that the autoantibodies inhibit ADPRP catalytic activity. In part, such precise epitope specificity could be attributed to the intrinsic antigenicity of the enzyme's active site. However, it is also reasonable to propose that the selective production of autoantibodies against the conserved catalytic site of ADPRP is influenced by exposure of the immune system to cross-reactive enzymes in the external environment. According to this hypothesis, foreign determinants on ADPRP from different species might act as carriers that facilitate the repeated stimulation of B lymphocytes producing cross-reactive antibodies reactive with the catalytic site of the human enzyme. In this regard, it is notable that human autoantibodies against alanyl-tRNA synthetase (33), RNA polymerase I (34), and topoisomerase I (35), have also been observed to inhibit the activities of these enzymes. Gilbert (32) originally suggested that the nucleotide binding domains of enzymes are encoded by distinct exons that have been shuffled from one gene to another during evolution. However, a relationship between the autoantigenic epitopes of nuclear proteins and particular exon units has not been established. A detailed comparison of the structure and organization of the ADPRP gene in different species should reveal whether or not the major autoantigenic region corresponds to one or more exons that are conserved in eukaryotic DNA.

\section{Acknowledgments}

We thank Drs. C. A. Penning, M. Ryuji, W. Yasui, and G. Harth for providing specimens, Dr. R. Fox for providing sera, D. B. Wasson and C. J. Carrera for helpful comments and suggestions, and N. Noon and J. Uhle for preparing the manuscript.

This work was supported in part by grants GM-23200, AR-25443, and RR-00833 from the National Institutes of Health and by a grant from the Council on Tobacco Research. This is Publication No. 5242BCR from Research Institute of Scripps Clinic, La Jolla, California.

\section{References}

1. Tan, E. M. 1982. Autoantibodies to nuclear antigens (ANA): their immunobiology and medicine. Adv. Immunol. 33:167-239.

2. Hardin, J. A. 1986. The lupus autoantigens and the pathogenesis of systemic lupus erythematosus. Arthritis Rheum. 29:457-460.

3. Yamanaka, H., E. H. Willis, C. A. Penning, C. L. Peebles, E. M. Tan, and D. A. Carson. 1987. Human autoantibodies to poly(adenosine diphosphate-ribose) polymerase. J. Clin. Invest. 80:900-904.

4. Pekala, P. H., and J. Moss. 1983. Poly ADP-ribosylation of protein. Curr. Top. Cell. Regul. 22:1-49.

5. Ueda, K., and O. Hayaishi. 1985. ADP-ribosylation. Annu. Rev. Biochem. 54:73-100.

6. Uchida, K., T. Morita, T. Sato, T. Ogura, R. Yamashita, S. Noguchi, H. Suzuki, H. Nyunoya, M. Miwa, and T. Sugimura. 1987. Nucleotide sequence of a full-length cDNA for human fibroblast poly(ADP-ribose) polymerase. Biochem. Biophys. Res. Commun. 148:617-622.

7. Kurosaki, T., H. Ushiro, Y. Mitsuuchi, S. Suzuki, M. Matsuda, Y. Matsuda, N. Katunuma, K. Kangawa, H. Matsuo, T. Hirose, S. Inayama, and Y. Shizuta. 1987. Primary structure of human poly(ADP-ribose) synthetase as deduced from cDNA sequence. J. Biol. Chem. 262:15990-15997.

8. Cherney, B. W., O. W. McBride, D. Chen, H. Alkhatib, K. Bhatia, P. Hensley, and M. E. Smulson. 1987. cDNA sequence, protein structure, and chromosomal location of the human gene for poly(ADP-ribose) polymerase. Proc. Natl. Acad. Sci. USA. 84:83708374.
9. Benjamin, R. C., and D. M. Gill. 1980. Poly(ADP-ribose) synthesis in vitro programmed by damaged DNA. A comparison of DNA molecules containing different types of strand breaks. J. Biol. Chem. 255:10502-10508.

10. Berger, N. A., G. W. Shikorski, S. J. Petzold, and K. K. Kurohara. 1979. Association of poly(adenosine diphosphoribose) synthesis with DNA damage and repair in normal human lymphocytes. J. Clin. Invest. 63:1164-1171.

11. Johnstone, A. P., and G. T. Williams. 1982. Role of DNA strand breaks and ADP-ribosyl transferase activity in eukaryotic differentiation demonstrated in human lymphocytes. Nature (Lond.). 300:368-370.

12. Fahey, J. L., and E. W. Terry. 1978. Ion exchange chromatography and gel filtration. In Handbook of Experimental Immunology. Vol. 1. D. M. Weir, editor. Alden Press, Oxford. 8.1-8.16.

13. Harth, G., C. G. Haidaris, and M. So. 1987. Neuraminidase from Trypanosoma cruzi: Analysis of enhanced expression of the enzyme in infectious forms. Proc. Natl. Acad. Sci. USA. 84:8320-8324.

14. Yamanaka, H., C. A. Penning, E. H. Willis, D. B. Wasson, and D. A. Carson. 1988. Characterization of human poly(ADP-ribose) polymerase with autoantibodies. J. Biol. Chem. 263:3879-3883.

15. Kameshita, I., Z. Matsuda, T. Taniguchi, and Y. Shizuta. 1984. Poly(ADP-ribose) synthetase. Separation and identification of three proteolytic fragments as the substrate-binding domain, the DNA-binding domain, and the automodification domain. J. Biol. Chem. 259:4770-4776.

16. Laemmli, U. K. 1970. Cleavage of structural proteins during the assembly of the head of bacteriophage T4. Nature (Lond.). 227:680-685.

17. Purnell, M. R., and W. J. D. Whish. 1980 . Nobel inhibitors of poly(ADP-ribose) synthetase. Biochem. J. 185:775-777.

18. Maniatis, T., E. F. Fritsch, and J. Sambrook. 1982. Enzymes used in molecular cloning. In Molecular Cloning. Cold Spring Harbor Laboratory, Cold Spring Harbor, NY. 113-114.

19. Mimori, T., and J. A. Hardin. 1986. Mechanism of interaction between Ku protein and DNA. J. Biol. Chem. 261:10375-10379.

20. Ushiro, H., Y. Yokoyama, and Y. Shizuta. 1987. Purification and characterization of poly(ADP-ribose) synthetase from human placenta. J. Biol. Chem. 262:2352-2357.

21. Wolin, S., and J. A. Steitz. 1984. The Ro small cytoplasmic ribonucleoproteins: identification of the antigenic protein and its binding site on the Ro RNAs. Proc. Natl. Acad. Sci. USA. 81:1996-2000.

22. Tan, E. M., G. Reimer, and K. Sullivan. 1987. Intracellular autoantigens: diagnostic fingerprints but an etiological dilemma. In Autoimmunity and Autoimmune Disease. D. Evered and J. Whelan, editors. John Wiley \& Sons Ltd., Chichester, UK. 25-42.

23. Earnshaw, W. C. 1987. Anionic regions in nuclear proteins. $J$. Cell Biol. 105:1479-1482.

24. Stanford, D. R., A. Rohleder, K. Neiswanger, and E. D. Wieben. 1987. DNA sequence of a human Sm autoimmune antigen. The multigene family contains a processed pseudogene. J. Biol. Chem. 262:9931-9934.

25. Chen, E. K. L., and E. M. Tan. 1987. Human autoantibodyreactive epitopes of SS-B/La are highly conserved in comparison with epitopes recognized by murine monoclonal antibodies. J. Exp. Med. 166:1627-1640.

26. Okolie, E. E., and N. I. Onyezili. 1983. ADP-ribosyltransferase in Plasmodium (malaria parasites). Biochem. J. 209:687-693.

27. Williams, G. T. 1985. ADP-ribosyltransferase in protozoan differentiation. In ADP-ribosylation of proteins. F. R. Arthaus, H. Hilz and S. Shall, editors. Springer-Verlag, Inc., New York. 358-366.

28. Scovassi, A. I., R. Izzo, E. Franchi, and U. Bertazzoni. 1986. Structural analysis of poly(ADP-ribose) polymerase in higher and lower eukaryotes. Eur. J. Biochem. 159:77-84.

29. Rechsteiner, M., D. Hillyard, and B. M. Olivera. 1976. Turnover of nicotinamide adenine dinucleotide in cultures of human cells. J. Cell. Physiol. 88:207-218. 
30. Penning, C. A., H. Yamanaka, D. A. Carson, C. L. Peebles, E. M. Tan, and K. F. Sullivan. 1987. Molecular cloning of poly(ADPribose) polymerase using human autoantibodies. Clin. Res. 35:566A. (Abstr.)

31. Michelson, A. M., C. C. F. Blake, S. T. Evans, and S. H. Orkin. 1985. Structure of the human phosphoglycerate kinase gene and the intron-mediated evolution and dispersal of the nucleotide-binding domain. Proc. Natl. Acad. Sci. USA. 82:6965-6969.

32. Gilbert, W. 1985. Genes-in-pieces revisited. Science (Wash. DC). 228:823-824.
33. Bunn, C. C., and M. B. Mathews. 1987. Autoreactive epitope defined as the anticodon region of alanine transfer RNA. Science (Wash. DC). 238:1116-1119.

34. Benavente, R., K. M. Rose, G. Reimer, B. Hugle-Dorr, and U. Scheer. 1987. Inhibition of nucleolar reformation after microinjection of antibodies to RNA polymerase I into mitotic cells. J. Cell Biol. 105:1483-1491.

35. Shero, J. H., B. Bordwell, N. F. Rothfield, and W. C. Earnshaw. 1986. High titers of autoantibodies to topoisomerase I (Scl-70) in sera from scleroderma patients. Science (Wash. DC). 231:737-740. 